\title{
ГЕОЛОГИЧЕСКОЕ РАЗВИТИЕ ОЗ. ЮЛЕМИСТЕ (ТАЛЛИН, ЭСТОНСКАЯ ССР)
}

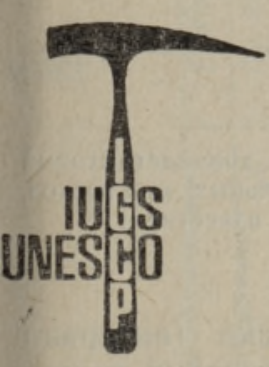

\section{Проект «Палео-} гидрология»

Оз. Юлемисте расположено в юго-восточной части Таллина в пределах разновозрастных озерно-морских террас Балтийского бассейна. Каплеобразное по форме озеро имеет площадь 960 га, максимальную ширину 3150 и длину 4465 м, объем воды 33,5 млн. ${ }^{3}$, среднюю и максимальную глубину 3 и 5 м соответственно. Берега слабо расчлененные, песчанистые, торфянистые, моренные, алевритистые, в прибрежной зоне с тростником, осокой и озерным схеноплектусом. Надводные склоны озерной ложбины слабо выражены, подводный склон западного берега сравнительно крутой с хорошо выраженным абразионным уступом в торфе. Регулируемый человеком уровень воды придерживается в среднем на абсолютной высоте 35,9 м.

С точки зрения народнохозяйственного значения изучению озера посвящено много работ, однако выявление и оконтуривание разнотипных донных отложений, уточнение палинологии и изучение диатомовой флоры дали авторам много нового фактического материала, позволяющего лучше осветить геологическое развитие озера и обосновать колебания уровня воды в нем.

Донные отложения. Коренной рельеф дна оз. Юлемисте и его окрестности разнообразен (Кюннапуу и др., 1981). Денудационные возвышения, относительной высотой 4-10 м, чередуются с эрозионными ложбинами, врезающимися в ордовикские известняки и кембрийские песчаники. В восточной части дно озера более или менее ровное, с обнажениями известняка ласнамягиского горизонта. В остальной части озера оно покрыто алевритом и песком, которые в пределах $70 \%$ покрыты сапропелем. Снизу вверх чередуются следующие разновидности сапропеля: торфянистый (центральная и северная части акватории) мощностью до $0,2-1,0$ м, который в углублении вдоль западного берега замещается плотной темно-коричневой разновидностью; известковистый сапропель мощностью до $2,9-3,1$ и сероватый жидкий тонкодетритовый сапропель мощностью до $3,0-3,5$ м; черный грубодетритовый сапропель (в пелогене) с малоразложившимися остатками осоки, тростника и со створками субфоссильных моллюсков (рис. 1,2 ); известковистый сапропель (южная часть озера), который в прибрежной зоне озера постепенно переходит в сапропелевую озерную известь.

В эталонном разрезе, из которого взяты пробы для палинологического, диатомового и литологического анализов, встречаются 


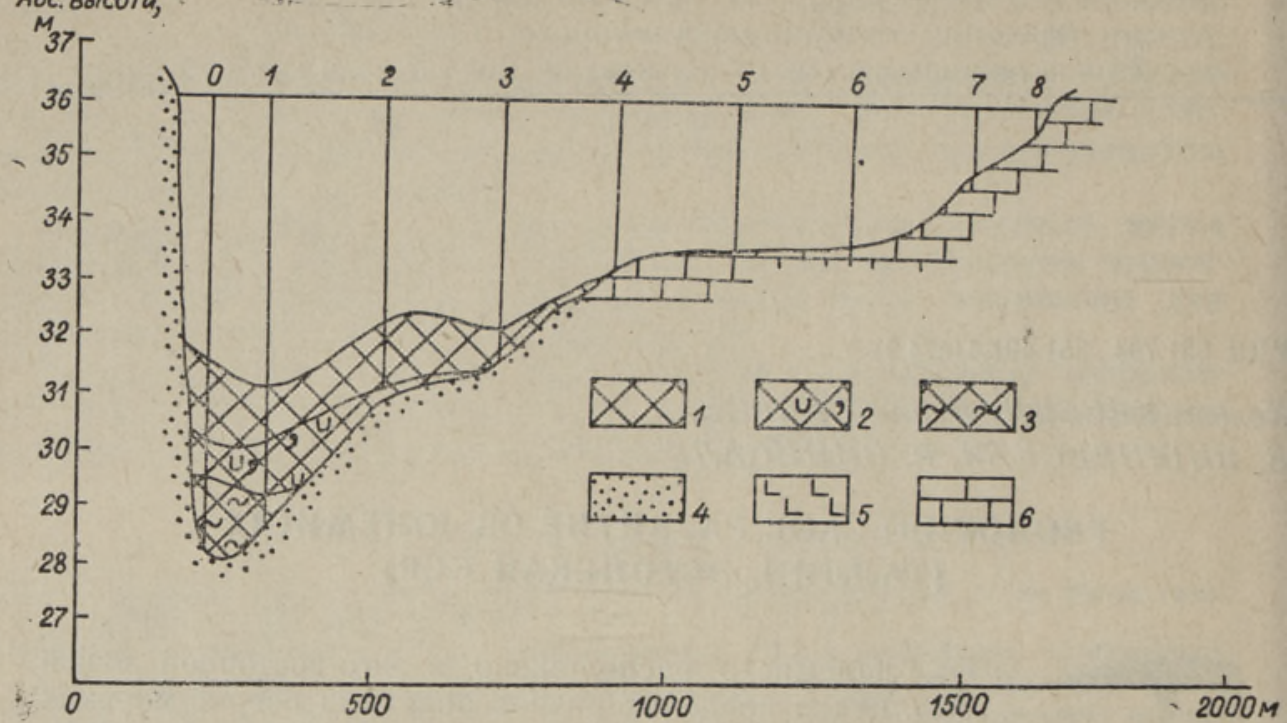

Рис. 1. Поперечный разрез 1 донных отложений оз. Юлемисте. 1 - тонкодетритовый сапропель, 2 - известковистый сапропель с фрагментами субфоссильных моллюсков, 3 - торфянистый сапропель, 4 - песок, 5 - алеврит, 6 - известняк.

следующие отложения: лагунные мелкозернистые пески (интервал $7,05-7,30$ м), формировавшиеся в раннем бореале; торфянистый сапропель (интервал $6,65-7,05$ м) - в бореале во время максимума пыльцы сосны. Ему характерно максимальное содержание органического вещества (OB) и минимальное количество карбонатного компонента (рис. 3) ; известковистый сапропель (интервал 4,35-6,65 м), формировавшийся на границе позднего бореала и атлантики, содержит СаO $30-35, \mathrm{MgO} 0,4-3,9$ и $\mathrm{SO}_{3} \quad 0,4-6,5 \%$. В составе его установлены кальцит, доломит, пирит и кварц. Самый верхний слой сапропеля (интервал $3,00-4,35$ м) накопился в течение суббореала. По рентгеноструктурным определениям он состоит из аморфной фазы кварца и кальцита. Общее содержание $\mathrm{OB}$ около $50, \mathrm{CaCO}_{3}$ - примерно 10 , терригенного компонента - $40 \%$ (рис. 3). Слои сапропеля, формировавшиеся в субатлантике, в данном разрезе отсутствуют. По всей вероятности, соответствующие отложения либо снесены волнами, достигающими дна мелководного современного озера, либо уничтожены выкачиванием сапропеля. В результате последнего не только повысилась мутность озерной воды, но и произошло секундарное обогащение ее питательными элементами (фосфором и азотом). В настоящее время в озере $1,0-1,2 \mathrm{мr} / л$ фосфора (на сухое вещество) и $15-17 \mathrm{мг/л} \mathrm{азота}$ (Loigu, Marksoo, 1982).

Палинологическая характеристика. В спорово-пыльцевой диаграмме эталонного разреза (рис. 4) выделены следующие палинозоны. В самой нижней части разреза, представленной мелкозернистым песком и торфянистым сапропелем (ннтервал $6,55-7,30 \mathrm{~m}$ ), наблюдается пыльца древесных пород с явным преобладаннем пыльцы сосны (до $84 \%$ ). В торфянистом сапропеле установлено высокое содержание споровых ников семейства Polypodiaceae (до 10\%). Состав пыльцы древесных пород показывает, что более нижние слои разреза следует отнести к бореалу, максимум которого фиксируется по четко выраженному уве- 

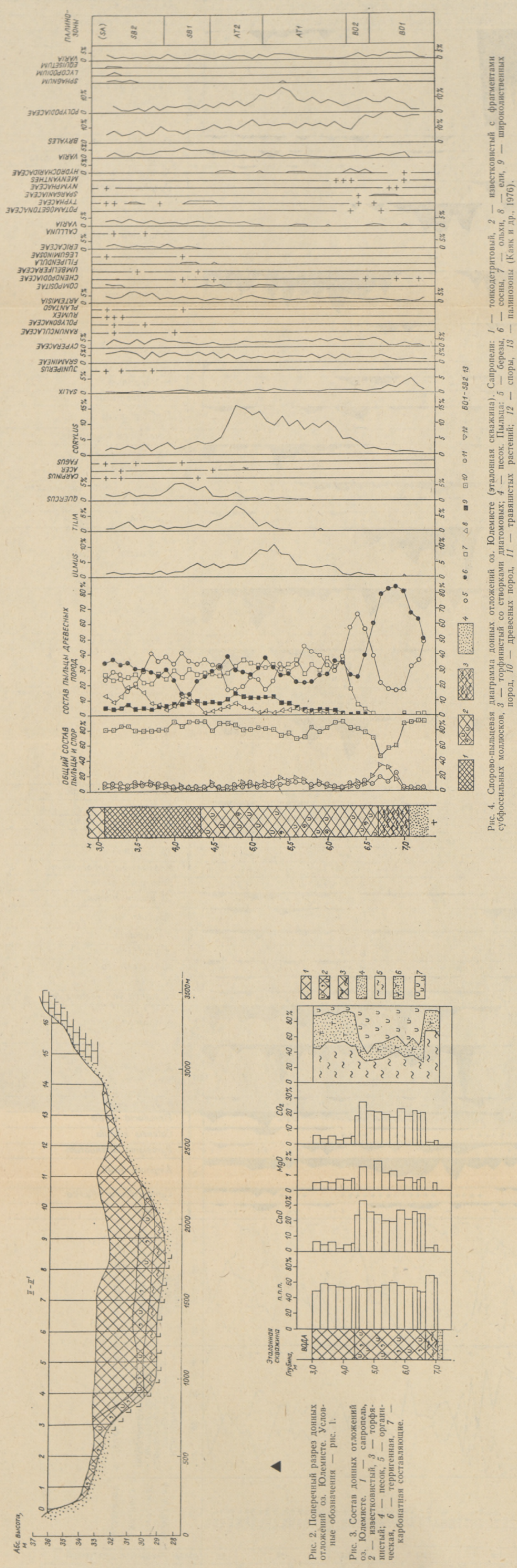


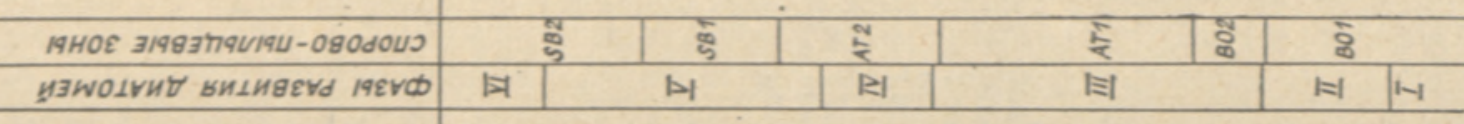
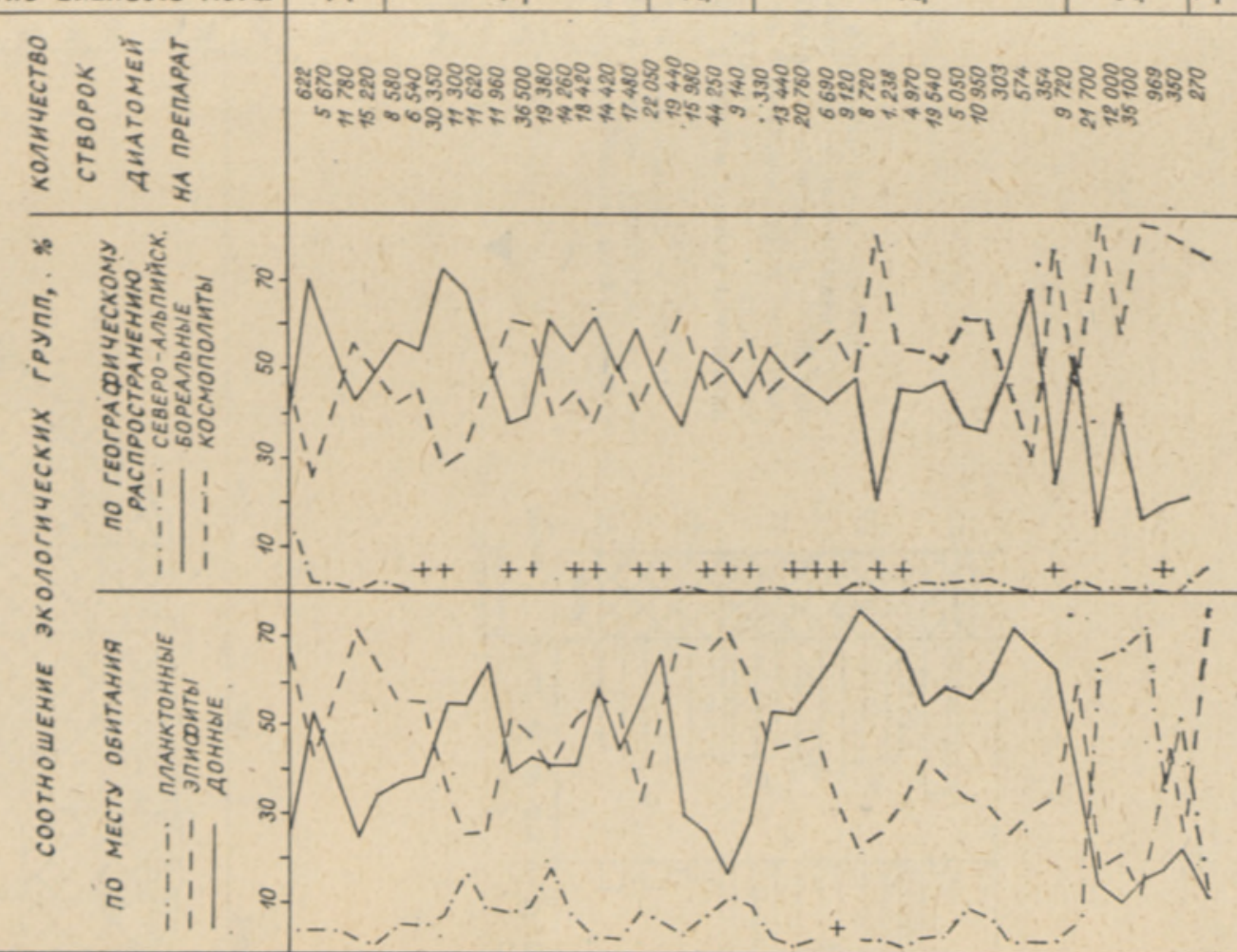

oajos :

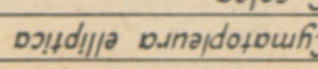

s/joso osoydui

intonuatho oub!soufig

D/nכ]|!s s!auop)

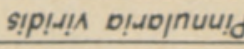

sap!oll|atnos $N$

!np/afuaouss $\mathrm{N}$

osolpos $N$

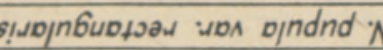

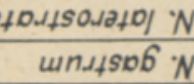

Dłop!dsno $N$

I.NOO סIIIIAON

uovatuas!uaoud is

osoydosabyds șiauozounouy

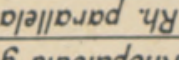

oq9!6 o!popdoy

a.upazdy

xasos dy

IIUuסupufy p!

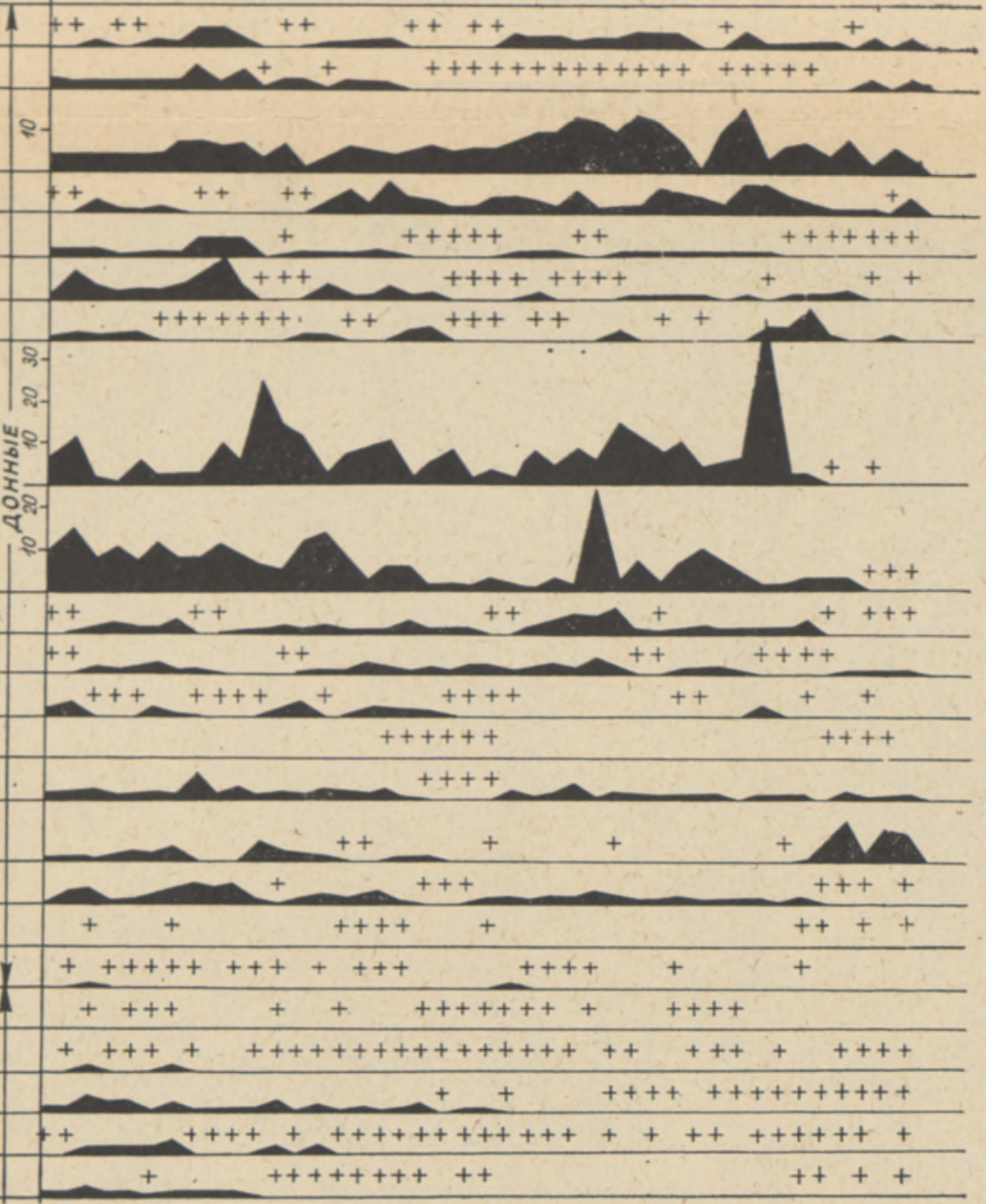

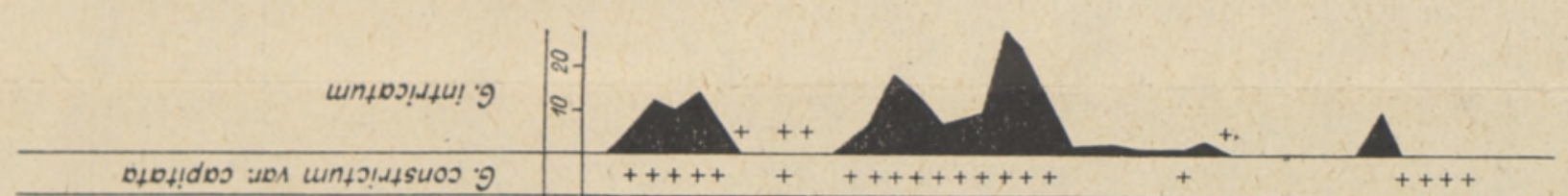

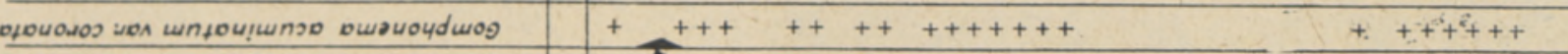

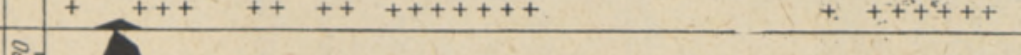

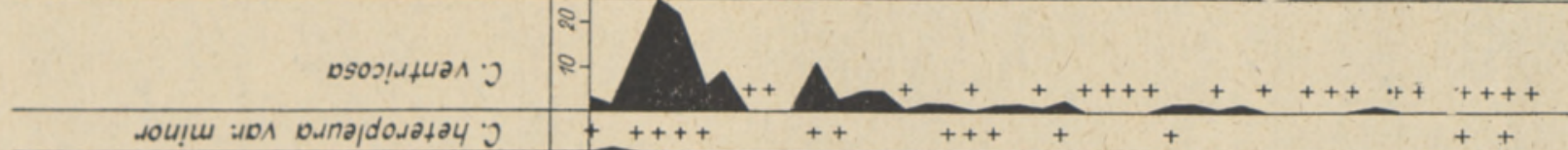

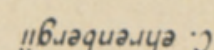

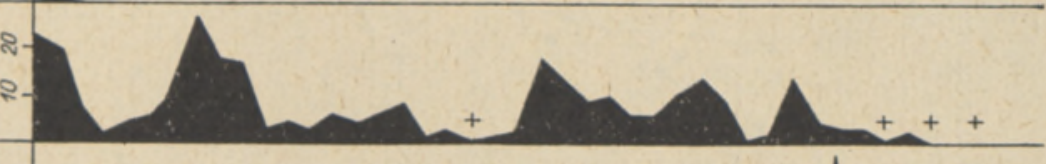

DUD!AmIIP

o/n+s!: 0

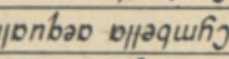
S!

ofDi/phonatay inos

оп6!xa sәчнивичрy

oriuoddo/ s!auosoornz

snous o!toung
Uounotsotdal ity

os!uoddol :y

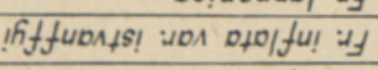

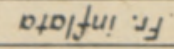

s!poulg :

suanมssuos :H

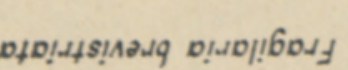

thituow oxoydado

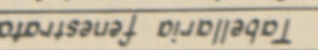

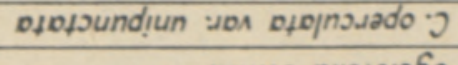

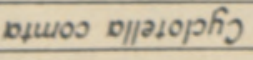

onbique oulso/aW
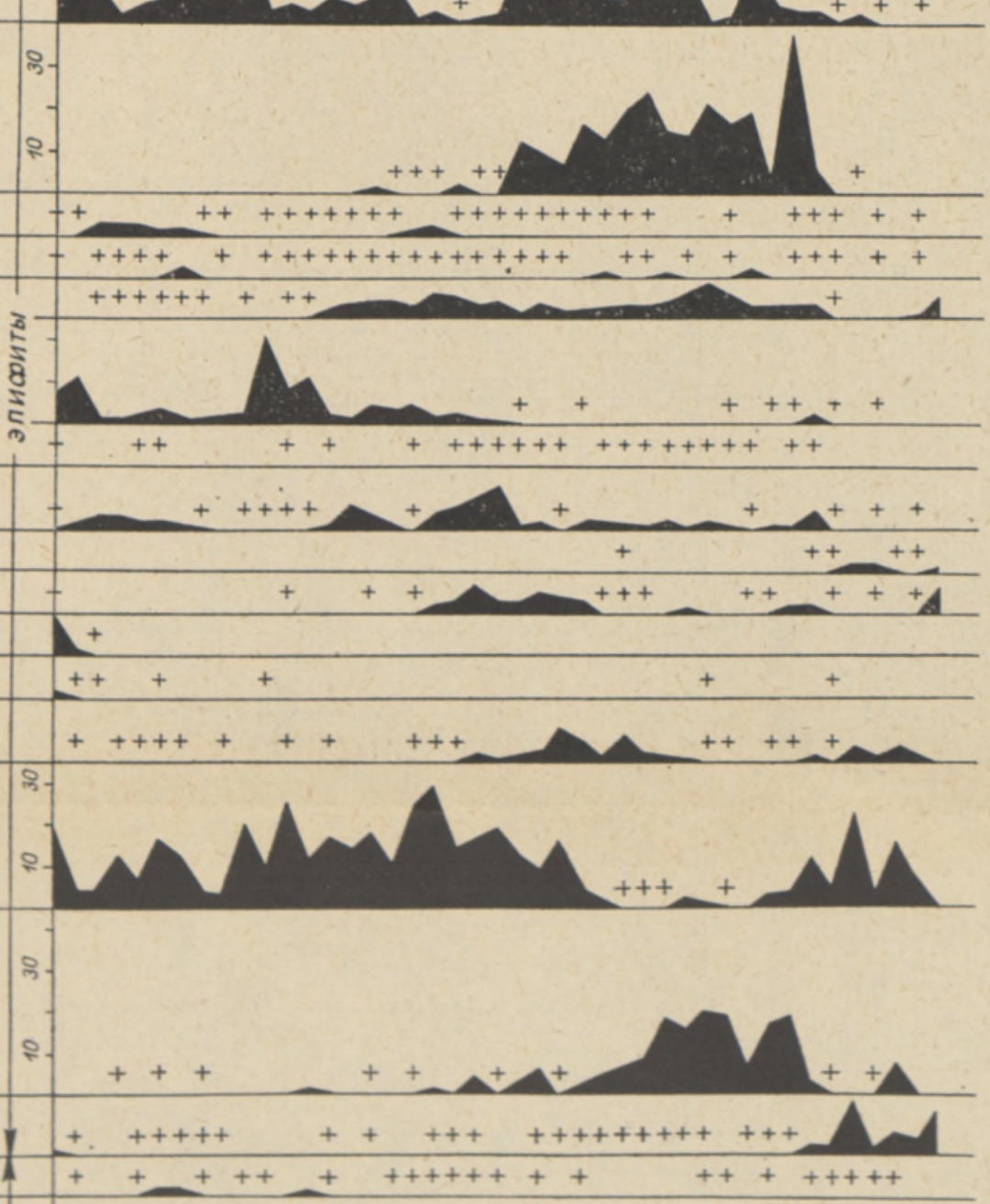

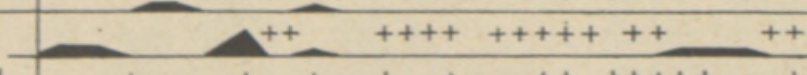
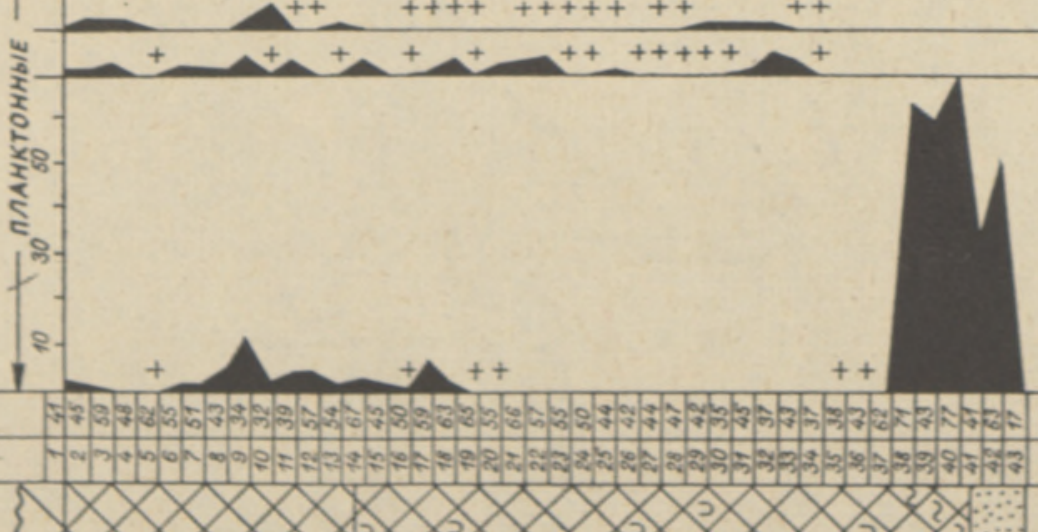
личению содержания пыльцы сосны (палинозона ВО1). Особенно характерно очень низкое содержание пыльцы березы и лещины и пыльцы ивы (до $5 \%$ ).

В нижней части известковистого сапропеля (интервал 6,25-6,55 м) среди господствующих древесных пород преобладает пыльца березы (до $66 \%$ ) и сосны (до $25 \%$ ). Количество пылыцы вяза и лещины небольшое, соответственно 2 и 5\%. В этом интервале разреза прослеживается резкое повышение пыльцы ольхи (от 4 до $30 \%$ ). Господство пыльцы березы и явное уменьшение количества пыльцы сосны отмечают границу между первой и второй половинами бореала, т. е. переход к зоне пыльцы лещины (палинозона ВО2). На границе данного и вышеприведенного интервалов произошло важное событие в развитии водоема - преобразование лагуны в прибрежное озеро.

Вверх по разрезу известковистый сапропель (интервал 6,25-4,50 м) характеризуется спорово-пыльцевыми спектрами с повышенным содержанием пыльцы широколиственных пород и высоким содержанием пыльцы ольхи. Например, широколиственные достигают максимума $(14 \%)$ на глубине 4,8 м. Максимум вяза (до $11 \%$ ) наблюдается в интервале 5,3 м, а максимум липы (до $8 \%$ ) на глубине 4,8 м. Пыльца лещины присутствует в разных интервалах от 6,0 до 4,8 м в количестве $11-16 \%$. Пыльца травянистых растен̆ий немногочисленна, доминируют споры папоротников (до $17 \%$ ) и зеленых мхов $(10-15 \%)$. Указанная часть разреза отнесена к атлантике, к палинозонам пыльцы вяза и липы (палинозоны АT1 и АT2).

Граница между атлантическими и суббореальными озерными отложениями в интервале 4,3-4,5 м определяется замещением известковистого сапропеля тонкодетритовым. В этом сапропеле явно повышается содержание пыльцы дуба до $6 \%$, а пыльцы других широколиственных пород становится меньше (палинозона SB1). Имеется также небольшой пик пыльцы ели (до 13\%). Количество пыльцы ольхи по-прежнему высокое, колеблется в пределах $24-30 \%$, а доминантной является пыльца березы (до 40\%). Возрастает количество пыльцы травянистых растений (злаки, полыни, разнотравье) и спор (сфагновые мхи). Вышеописанные спектры сапропеля принадлежат нижней половине суббореала или к зоне пыльцы дуба.

Граница между обеими суббореальными зонами находится примерно в интервале $3,8-3,9$ м, где начинается повышение содержания пыльцы ели до 20\%. Основную часть тонкодетритового сапропеля следует отнести к зоне пыльцы нижней ели (палинозона SB2).

Методом диатомового анализа установлены 140 видов и разновидностей диатомей, среди которых доминируют роды Melosira, Fragilaria, Cocconeis, Navicula, Cymbella и Epithemia (рис. 5). Встречаемость диатомей в пробах различна, с максимумом в интервале $3,6-6,1$ м, где на препарат отмечено от 11 до 44 тыс. створок диатомей и 35-66 таксонов. Әкологический анализ состава диатомей показал, что подавляющее большинство видов - типичные обитатели пресных вод, лишь с некоторыми галофильными формами (не более $8 \%$ общего количества видов).

В мелкозернистом песке $(7,2-7,3$ м) обнаружен скудный по составу пресноводный диатомовый комплекс (17 таксонов) с преобладанием представителей эпифитов родов Fragilaria, Opephora и Amphora обитателей мелководной прибрежной зоны водоема на этом этапе развития оз. Юлемисте. Здесь отмечены единичные створки двух солоноводных видов: Nitzschia navicularis и Campylodiscus echeneis, по-видимому, переотложенных из нижележащих отложений. Следующий, второй период $(6,6-7,2$ м), охватывает первую половину бореала. Состав 
диатомей характеризуется интенсивным развитием планктонного вида Melosira ambigua (до $70 \%$ ), а также отмечены виды рода Cyclotella (до $4-6 \%)$. Третий период в развитии диатомей $(5,2-6,6$ м) соответствует палинозонам ВО2 и АТ1. Ведущую роль в диатомовом комплексе играют донные виды (до 70\%) и виды обрастаний (до $30 \%$ ), представители Fragilaria, Mastogloia, Cymbella, Cymatopleura и др., указывающие на мелководность озера на этом этапе.

Следующий, четвертый период $(4,8-5,2$ м), характеризуется преобладанием видов обрастаний (эпифитов) (до $70 \%$ ), донные формы составляют до 30 , планктонные не превышают $11 \%$. Обилие первых свидетельствует о зарастании водоема и образовании мелководного озера. На пятом этапе $(3,5-4,8$ м), к которому относятся конец палинозоны AT2, палинозона SB1 и начало палинозоны SB2, вновь наблюдается незначительное повышение уровня водоема. В составе диатомей - планктонная Melosira ambigua вместе с видами р. Cyclotella и Fragilaria fenestrata (до 19\%). Преобладающими остаются эпифиты высшей водной растительности (до $57 \%$ ). В этом периоде уровень озера повышался, о чем свидетельствует и замещение известковистых разновидностей сапропеля кремнеземистыми. Последний, шестой этап $(3,0-3,5)$, охватывает конец суббореала. В соответствующих отложениях диатомей обрастания достигают $66-73$, донные виды $25-52$, планктонные менее $5 \%$.

Таким образом, данные диатомового анализа позволили проследить трансгрессию Анцилового озера, зафиксированную в песках в первой половине бореала. Второе незначительное повышение уровня воды в ложбине озера приходится на конец атлантики и суббореала. Преобладание диатомей донных видов и обрастаний свидетельствует о возникновении озерного мелководья в течение палинозон ВО2, АТ1 и АТ2. Повышением уровня воды во время суббореала сопровождалось увеличение проточности, но в конце названного периода водоем снова мелеет и зарастает.

Общий состав диатомового комплекса, незначительная роль в нем холодноводных северо-альпийских форм (менее $5 \%$ ) и бореальный характер комплекса, обусловленные невысоким стоянием уровня воды в озере и хорошо прогреваемой водной толщью, способствовали развитию следующих видов: Fragilaria brevistriata Grun., Fr. construens (Ehr.) Grun., Navicula oblonga Kütz., N. cari Ehr., N. Schoenfeldii Hust., N. cuspitata Kütz., Stauroneis acuta W. Sm., Anomoeoneis sphaerophora (Kütz.) Pfitz., Cymbella diluviana (Krasski) Florin, C. ehrenbergii Kütz., C. ventricosa Kütz. и других, типичных для озер эвтрофного типа.

Палеогеографические выводы. После отступления края ледника валдайского оледенения окрестность Таллина была залита водами Балтийского ледникового озера и лишь в конце его распространения здесь сформировался архипелаг (рис. 6A). Примерно 10200 лет назад в связи с отступлением края ледника севернее Биллингена (Средняя Швеция) уровень воды резко понизился: на 26 м в Швеции и 26-28 м в Финляндии (Donner, 1982). Это событие положило начало Иольдиевому морю. В этот период оз. Юлемисте было прибрежной зоной названного моря (рис. 65 ). Соответствующая береговая линия осталась на абсолютной высоте (около 40 м). В связи с регрессией Иольдиевого моря во время поздней половины пребореала уровень воды в Балтийском бассейне понизился примерно на 10 м. В начале бореала при кульминации Анцилового озера в ложбине оз. Юлемисте сформировалась неглубокая зачаточная лагуна с уровнем воды до 37 м, имеющая два узких соединения с открытым бассейном в северной и 
A

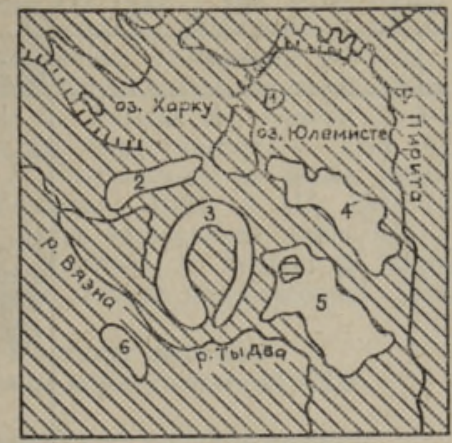

B
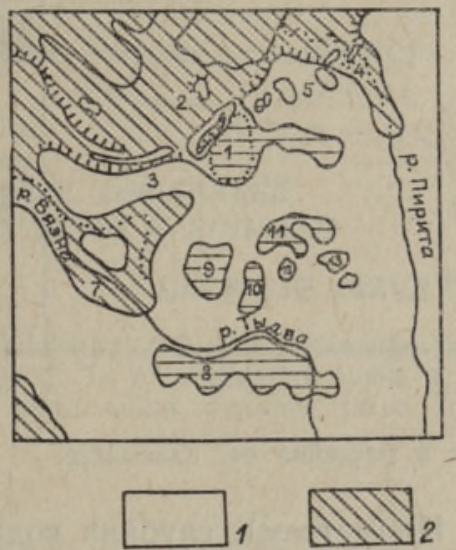

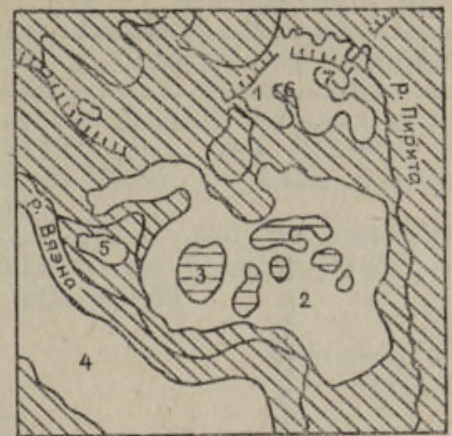

$\Gamma$

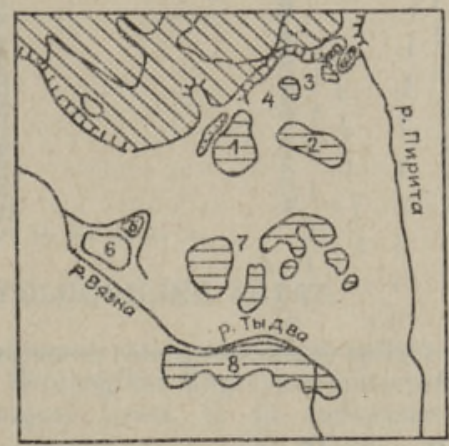

$E{ }_{3}+\mathrm{w}_{4} \otimes_{5}$

Рис. 6. Палеогеографнческие схемы развития оз. Юлемисте и его окрестности. 1 суша, 2 - море нли крупное озеро, 3 - лагуна, прибрежное озеро или болото, 4 - глинт Северной Эстонии и береговые уступы, 5 - пересыпь и прибрежные дюны. A - Архипелаг в конце стадии Балтийского ледникового озера. Основные острова в этом архипелаге находились на: Ласнамяэском карбонатном плато (1), Ныммеской флювиогляциальной дельте (2), Мянникуской флювиогляциальной дельте (3), возвышении Мыйгу-Лехмья (4), возвышении Сайре-Курна (5), возвышении Яльгимяэ (6).

E - Распространение максимальной береговой линии Иольдиевого моря: острова на Ласнамяэском карбонатном плато (1) и между поселками Нымме и Курна (2), прибрежные озера Валдеку и др. (3), полуостров между реками Вяэна и Кейла (4), остров на возвышении Пяэскюла (5), лагуны Сыямяэ (6) и Тонди (7).

$B$ - Распространение максимальной береговой линии Анщилового озера: лагуны Юлемисте и Раэ (1), остров возвышения Тоомпеа (2), береговые уступы и прибрежные дюны в отложениях Ныммеской флювногляциальной дельты и на прибрежной полосе подножья этой дельты (3), пересыпь Иру и лагуна в устье р. Пирита (4), прибрежные озера Тонди (5) и Сыямяэ (6), бухта с небольшим островом Пяэскюла (7), озера Саку-Саусти (8) и Валдеку (9), озера и болота Вяэла, Лехмья, Венекюла и Курна $(10-13)$.

$\Gamma$ - Распространение максимальной береговой линии Литоринового моря. Озера: Юлемисте (1), Раэ (2), Тонди (3), Сыямяэ (4), Пяэскюла (5), Саку-Саусти (8); возвышение Пяэскюла (6), болото Валдеку (7).

юго-западной частях ложбины (рис. $6 B$ ). В этой лагуне накопились пески и алевриты, возраст которых, по данным спорово-пыльцевого анализа, соответствует началу или ранней половине бореала. Через несколько сотен лет зачаточная лагуна перешла в истинную, которая существовала здесь в течение ранней половины бореала. В этой лагуне накопился торфянистый сапропель. Как показывают состав пыльцы водных растений (рис. 4, 6,6-7,0 м) и содержание макрофитов тор- 


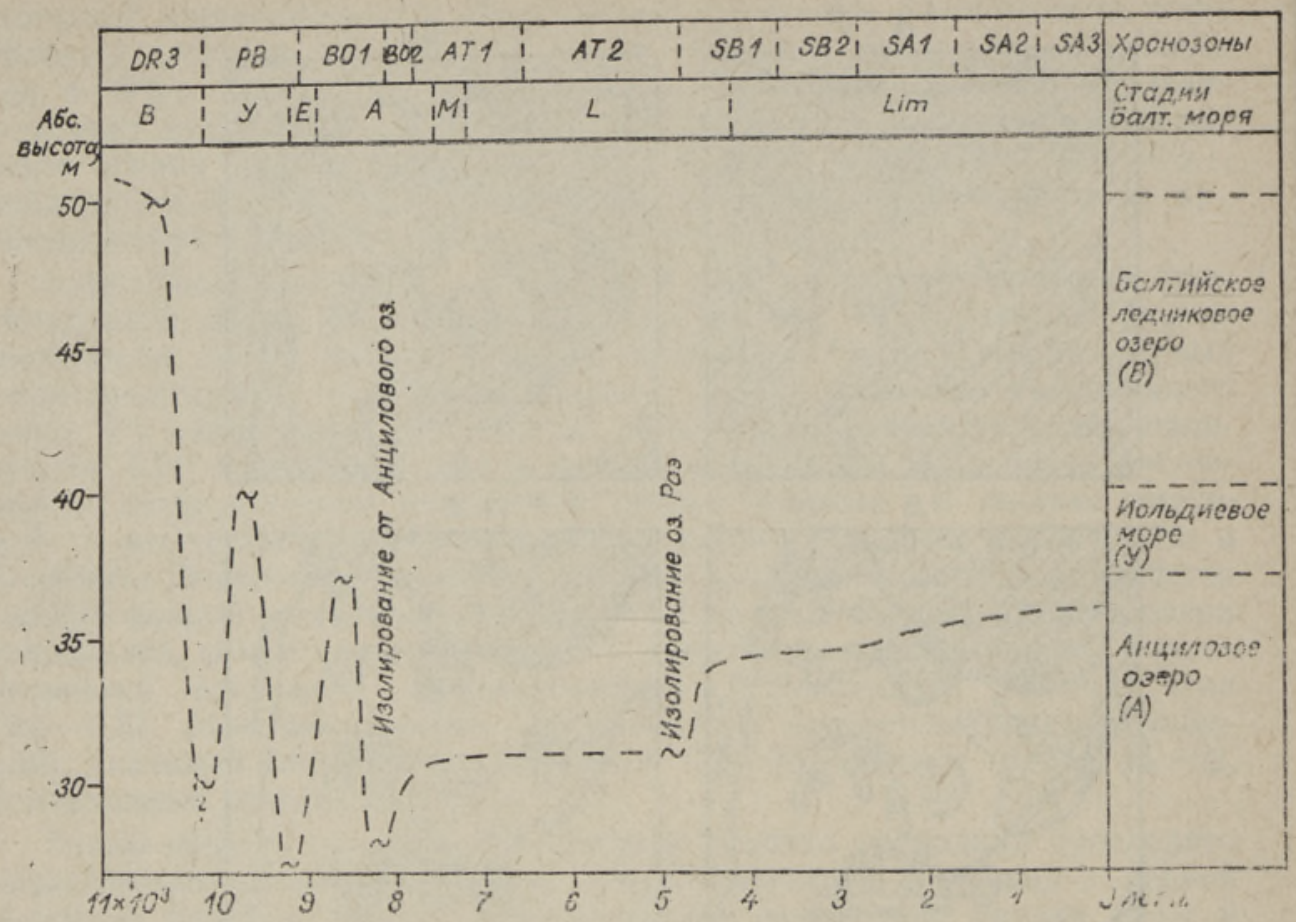

Рис. 7. Изменение уровня воды в бассейне оз. Юлемисте.

фянистого сапропеля (определено М. Илометсом), глубина воды в лагуне была незначительная, примерно $0,5-1,0$ м, с уровнем $28-29$ м. (рис. 7). Найденные виды (Drepanocladus fluitans - 25, D. lycopodioides - 10, Scorpidium scorpioides - 30, Sphagnum fimbriatum - 20, S. squarrosum -5 , Carex diandra -5 , Menyanthes trifolium $-5 \%$ ) говорят о заболоченности ложбины лагуны и о постоянно открытой водной поверхности, об этом же свидетельствуют и результаты диатомового анализа, выявившие преобладание планктонных.

В ходе регрессии Анцилового озера окончательно сформировалась коса Юлемисте, которая закрыла соединение лагуны с Анциловым озером, и в ложбине началось запруживание подземных вод. Это привело к образованию самостоятельного прибрежного озера, где в поздней половине бореала осадконакопление торфянистого сапропеля сменилось формированием пресноводного известковистого сапропеля. Однородные экологические условия озера не изменялись в течение длительного времени, о чем свидетельствует толща извесстковистого сапропеля от бореала до начала суббореала.

Радиоуглеродная датировка, установленная на основании донных слоев известковистого сапропеля в северной части современного озера $(8300 \pm 90$ :TA-691; Ilves, 1980), фиксирует время перехода лагуны к прибрежному озеру примерно 8300-8400 лет назад.

В начале суббореала характер седиментации резко изменился, так как началось накопление тонкодетритового сапропеля. Это явление связано с местными условиями осадкообразования и прежде всего с углублением седиментационного бассейна. Несомненно, сыграло роль и отделение оз. Юлемисте от прибрежного оз. Раэ в конце атлантики (рис. $6 \Gamma$ ). Имея в виду, что базальные слои тонкодетритового сапро-

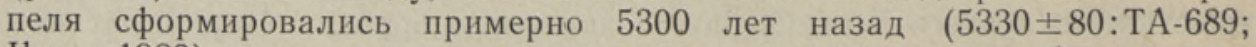
Ilves, 1980), названное разделение озер имело место приблизительно 5400 лет назад. 
Каяк К., Кессел Х., Лийвранд Э., Пиррус Р., Раукас А., Сарв А. Стратиграфия четвертичных отложений Эстонии. - В кн.: Стратиграфия четвертичных отложений Прибалтики. Вильнюс, $1976,4-52$.

Кюннапуу C., Раукас А., Таваст Э. Рельеф поверхности коренных пород в Таллине и его окрестностях. - Изв. АН ЭССР. Геол., 1981, 30, № 4, 167-172.

Donner, J. Fluctuations in water level of the Baltic Ice Lake. - Ann. Acad. Sci. Fennicae., 1982, A III, 134, 13-28.

Ilves, E. Tartu radiocarbon dates X. - Radiocarbon, 1980, 22, 1084-1089.

Loigu, E., Marksoo, P. Fosfori ja lämmastiku bilanss Olemiste järves. - Rmt.: Eesti NSV järvede nüüdisseisund. Tartu, 1982, 32-39.

\author{
Ннститут геологии \\ Академии наук Эстонской ССР
Ленинарадский государственный университет

Поступила в редакцию

$31 / \mathrm{X} 1983$

Управление геологии Эстонской ССР

Helgi KESSEL, Leili SAARSE,

E. VISNEVSKAJA, R. SINISALU

\title{
OLEMISTE JARVE GEOLOOGILINE ARENG
}

Artiklis on käsitletud Olemiste järvenõos kuhjunud setete lasumust, levikut (joon. 1-2), koostist (joon. 3), stratigraafiat (joon. 4), ökoloogilisi tingimusi diatomeefloora põhjal (joon. 5) ning antud ülevaade järve arengust (joon. 6) ja veetaseme kōikumistest (joon. 7).

Helgi KESSEL, Leili SAARSE,

E. VISHNEVSKAYA, R. SINISALU

\section{GEOLOGICAL DEVELOPMENT OF LAKE OLEMISTE (TALLINN, ESTONIAN SSR)}

Lake Ulemiste as the main supplier of fresh water to Tallinn has been under an immediate human impact for almost a hundred years. That eutrophic lake lies in the south-eastern part of the city at an altitude of $35.9 \mathrm{~m}$. The lake is shallow, the maximum and average depths being 5 and $3 \mathrm{~m}$ respectively, the area 960 ha.

Lake sediments consist of varying layers of gyttja (peaty, calcareous, fine detritus, Figs $1-3)$. They are underlain by till, silt, sand and carbonate bedrock which crop out in the eastern part of the lake. Geological, palynological and diatom studies have revealed that lake sediments with a thickness of $4-5 \mathrm{~m}$ represent a sequence starting from the Early Boreal (Fig. 4). The deposition of sand and peaty gyttja took place during the Early Boreal in a lagoon which was finally isolated from the Ancylus Lake at the end of palynozone BO1, about 8300-8400 years ago (Fig. 6). During the regression of the Littorina Sea, the coastal lakes Ulemiste and Rae were separated from one another, and in the basin of L. Ulemiste a deposition of fine detritus gyttja took place. On the basis of radiocarbon datings that event occurred about 5400 years ago. Diatom studies of the lake deposits (Fig. 5) entitle us to conclude that the water level was relatively high at the beginning of the Early Boreal (during the Ancylus transgression) and Subboreal, and low during the palynozones BO2, AT1 and AT2 (Fig. 7). 